\title{
Pathological and Microbiological Investigations of Naturally Infected Rainbow Trout (Oncorhynchus mykiss) with Flavobacterium psychrophilum
}

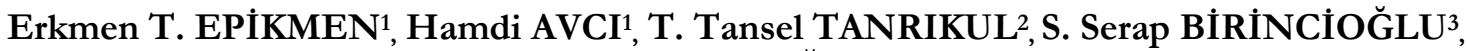 \\ Ahmet AYDOĞAN"** \\ ${ }^{1}$ Department of Pathology, Faculty of Veterinary Medicine, Aydin Adnan Menderes University, Aydin, Turkey \\ ${ }^{2}$ Department of Aquaculture and Fish Diseases, Faculty of Fisheries, Izmir Katip Celebi University, Izmir, Turkey \\ 3 Special A Pathology Laboratory, Izmir, Turkey \\ ${ }^{4}$ Department of Pathology, Faculty of Ceyhan Veterinary Medicine, Cukurova University, Adana, Turkey
}

\begin{abstract}
It was aimed to identify and evaluate the pathological and microbiological findings in rainbow trout naturally infected with Flavobacterium psychrophilum in two trout farms of Aydın and Muğla within this study. A total of 77 rainbow trout (Oncorbynchus mykiss) (weighing $1 \pm 02 \mathrm{~g}$ and 5-6 $\mathrm{cm}$ in size) were collected from two separate trout farms. The most common lesion seen in macroscopic examination was petechial hemorrhages that formed on the skin in different parts of the body. In addition, skin erosion and ulcers, exophthalmus and periocular hemorrhages were observed in the eyes. Microscopically, erosive foci in some areas, and ulcers in which the destructions reached the muscle layer in some areas were noted. There were bacteria clusters, hemorrhages and inflammatory cell infiltrations consisting of macrophages and lymphocytes in the ulcer foci. As a result of the bacteriological examination, the isolated bacteria were identified as Flavobacterium psychrophilum based on their morphological and biochemical character.
\end{abstract}

Keywords: Flavobacterium psychrophilum, pathology, microbiology, rainbow trout, natural infection

\section{$* * *$ \\ Flavobacterium psychrophilum ile Doğal Enfekte Gökkuşağı Alabalıklarında (Oncorhynchus mykiss) Patolojik ve Mikrobiyolojik İncelemeler}

ÖZ

Bu çalısma ile Aydın ve Muğla illerinde bulunan iki alabalık işletmesinde Flavobacterium psychrophilum ile doğal enfekte gökkuşağı alabalıklarında şekillenen patolojik ve mikrobiyolojik bulguların tanımlanarak birlikte değerlendirilmesi amaçlanmıştır. İki ayrı alabalık işletmesinden toplanan $1 \pm 02 \mathrm{~g}$ ağırlığında ve 5-6 cm büyüklüğünde toplam 77 adet gökkuşağ1 alabalığ1 (Oncorbynchus mykiss) incelendi. Makroskobik incelemede en yaygin görülen lezyon, vücudun değişik bölgelerinde deride şekillenen peteşiyel kanamalardı. Buna ek olarak, deride erozyon ve ülserler, gözlerde ekzoftalmus ve perioküler kanama görüldü. Mikroskobik olarak, bazı alanlarda epidermisin yüzeysel olarak yıkımlandığı eroziv odaklar, bazı alanlarda ise yıkımlanmaların kas tabakasına dek ulaştı̆̆ ülserler dikkati çekti. Ülser odaklarında bakteri kümeleri, kanamalar ile makrofaj ve lenfositlerden oluşan yangısal hücre infiltrasyonları mevcuttu. Yapılan bakteriyolojik inceleme sonucu, izole edilen bakteri morfolojik ve biyokimyasal karakterine göre Flavobacterium psychrophilum olarak identifiye edildi.

Anahtar Kelimeler: Flavobacterium psychrophilum, patoloji, mikrobiyoloji, gökkuşağı alabalığı, doğal enfeksiyon

To cite this article: Epikmen E.T. Avc H. Tanrkul T.T. Birincioğlu S.S. Aydoğan A. Pathological and Microbiological Investigations of Naturally Infected Rainbow Trout (Oncorbynchus mykiss) with Flavobacterium psychrophilum. Kocatepe Vet J. (2020) 13(2):172-178

Submission: 14.02.2020 Accepted: 20.05.2020 Published Online: 22.05.2020

ORCID ID; ETE: 0000-0003-2641-2321, HA: 0000-0002-7776-5373, TTT: 0000-0002-1684-7965, SSB: 0000-0001-5815-6508, AA: 0000-0003-2504-8150

*Corresponding author e-mail: aaydogan@cu.edu.tr 


\section{GİRİ̧}

Günümüzde sürekli bir gelişim içinde olan kültür balıkçılı̆̆ı sektöründe balık hastalıklarına bağlı kayıplar işletmelerde önemli ekonomik sorunlara neden olmaktadır. Bu kayıpların nedenleri arasında bakteriyel hastalıklar geniş yer tutar. Bu hastalıklardan biri de son 20 yilda tüm dünyada salmonidlerde ve özellikle de yavrularında çok ciddi sorunlara yol açan, düşük su sicaklıklarında $\left(<10{ }^{\circ} \mathrm{C}\right)$ meydana geldiğinden dolay1 bakteriyel soğuk su hastalı̆g olarak da bilinen, Flavobacterium psychrophilum (F. psychrophilum)'un neden olduğu hastalıktır (Roberts 2001, Ekman ve Norrgren 2003). Avrupa'da hastallğın etiyolojisinin tanımlanmadığ1 dönemlerde fry mortalite sendromu ya da gökkuşağı alabalıklarının (Oncorbynchus mykiss) fry sendromu (RTFS) olarak adlandırılmıştır (Roberts 2001, Nematollahi ve ark. 2003). Etken, Flavobacteriaceae familyasinin Flavobacterium genusunda yer alan, gram negatif, sporsuz, kapsülsüz, aerobik ya da fakültatif aerobik bir basildir. Gökkuşağ̣ alabalıkları F. psychropbilum enfeksiyonuna karş1 oldukça duyarlıdır. Özellikle 0.5-2.0 g'lık yavru balıkların enfeksiyondan çok fazla etkilendiği ve yüksek (\%50-70) mortalite oranlarının kaydedildiği bildirilmiştir (Roberts 2001, Madsen ve ark. 2005).

Sunulan çalışmada, Aydın ve Muğla illerinde bulunan iki alabalık işletmesinde yavru gökkuşağ1 alabalıklarında F. psychrophilum'un oluşturduğu doğal enfeksiyonun patolojik ve bakteriyolojik bulgularının tanımlanması amaçlanmıştır.

\section{Hayvan Meteryali}

\section{MATERYAL ve METOT}

Çalışmanın materyalini Aydın ve Muğla illerinde bulunan iki alabalık işletmesinden toplanan $1 \pm 0.2 \mathrm{~g}$ ağırlığında ve 5-6 cm uzunluğunda, hasta ya da hastalık şüphesi olan, yeni ölmüş veya öldürülen toplam 77 adet gökkuşağı alabalığ (Oncorbynchus mykiss Walbaum, 1792) oluşturdu.

\section{Patolojik Analiz}

Nekropsiyi takiben alınan doku örnekleri \%10'luk tamponlu formalin solüsyonunda tespit edildi, trimleme işleminden sonra rutin olarak alkol ve ksilol serilerinde takip edildi, daha sonra parafinde bloklandi. Bu bloklardan mikrotomda alınan kesitlerin tamam1 (4-6 $\mu \mathrm{m})$ hematoksilen-eozin (HE) ile boyanarak ışı1k mikroskobunda incelendi.

\section{İzolasyon ve İdentifikasyon}

Mikrobiyolojik inceleme için balıkların böbrek ve dalağından aseptik olarak alınan örneklerden Cytophaga Agar üzerine bakteriyolojik ekim yapildı. Besi yerinde $15 \pm 2{ }^{\circ} \mathrm{C}$ 'de 14 gün inkübe edildi. İzole edilen bakteri morfolojik ve biyokimyasal özellikleri dikkate alınarak identifiye edildi (Austin ve Austin 1987). Bakterinin API 20E striplerine inokulasyonunda steril PBS'de Mac Farland No: 4 yoğunluğunda homojenize edilmiş kültür kullanıldı ve API 20E test (Bio Merieux S.A.) sonuçları değerlendirildi (Austin ve Austin 2007). Bakterinin morfolojik yapisı hem natif hem de Gram boyama yöntemiyle boyandiktan sonra incelendi. Dalaktan hazırlanan sürme froti metanol ile tespit edildikten sonra fuksin ile boyandı. Biyokimyasal testlerden kitin ve agar hidrolizasyonu (Reichenbach ve Dworkin 1981), nişasta ve euskilin hidrolizi, jelatin ve kazein hidrolizasyonu (Pacha ve Porter 1968) yapildı. Bakterilerin farklı sicakliklarda üreme kabiliyeti Anacker ve Ordal Broth (AOB)'da, tuza karş1 tolerans1 \% 0.5, 1,2,3 NaCl ilave edilen tuzlu AOB'de tespit edildi. Tributrin, tween 20 ve tween 80 degradasyon testleri Anacker ve Ordal Agar (AOA) üzerinde yapildı.

\section{BULGULAR}

Balıklarda klinik olarak durgunluk, yem tüketiminde azalma ve su yüzeyine yakın yüzmeler ile düzensiz yüzme hareketleri gözlendi.

Makroskobik incelemede en yaygın görülen lezyon vücudun değişik bölgelerinde deride şekillenen peteşiyel kanamalardı (Şekil 1). Derinin renginde koyulaşma (Şekil 2) ve pullarda dökülme ile erozyon ve derin kas katmanlarına kadar yerleşim gösteren ülserler (Şekil 3) deride görülen diğer makroskobik bulgulardi. Gözlerde ekzoftalmus ile birlikte birçok balıkta perioküler kanamalar saptandı (Şekil 4A ve B). Bazı solungaçlarda anemi (Şekil 4C), bazılarında ise hiperemi ve peteşiyel kanamalar görüldü. Birçok balıkta asites oldukça belirgindi. Karaciğer, dalak (Şekil 4D) ile böbrekler şişkin ve yumuşak kıvamlıydı. Hava kesesinde ödem ve yer yer kalınlaşmalar dikkati çekti.

Mikroskobik olarak, birçok balıkta epidermiste erozyon belirlendi. Bazı alanlarda eroziv odaklarin derin kas tabakalarına kadar ulaşan ülserlere dönüştüğü görüldü. Ülser alanlarında bakteri kümeleri, kanamalar ile makrofaj ve lenfositlerden oluşan yangisal hücre infiltrasyonları mevcuttu (Şekil 5). Solungaçlarda yaygin olarak primer lamellerde hiperemi ile sekonder lamellerde ödem, epitellerde dejenerasyon ve dökülmeler gözlendi (Şekil 6). Bazı balıklarda lameller arasında yabanc1 partiküller belirlendi. Kalpte epikarditis önemli bir bulgu olarak dikkati çekti. Epikard yoğun mononüklear hücre infiltrasyonlanı ile kalınlaşmıştı (Şekil 7). Peritonda kanama ve mononüklear hücre infiltrasyonu görüldü. Benzer kanamalara abdominal yağ dokuda da rastlandi. Karaciğerde damarlar hiperemikti ve hepatositlerde dejenerasyon görüldü. Dalakta sinüzoidler eritrositler ile doluydu. Böbrekte damarlar hiperemikti ve tubulus epitellerinde dejenerasyon ile 
birlikte sitoplazmalarında eozinofilik hyalin damlacıkları dikkati çekti (Şekil 8).

Mikrobiyolojik olarak Cytophaga Agar üzerinde 10 günde saf sarı renkli koloniler üredi. Dalaktan hazırlanan sürme frotide çok miktarda ince uzun basiller görüldü. Sar1 renkli bu koloniler bakterinin identifiye edilmesi için biyokimyasal test besi yerlerine inokule edilerek fenotipik özellikleri saptand. Bakterinin morfolojik ve biyokimyasal karakterlerine göre (Tablo 1 ve 2 ) hastalığın etkeni F. psychrophilum olarak identifiye edilmiştir.

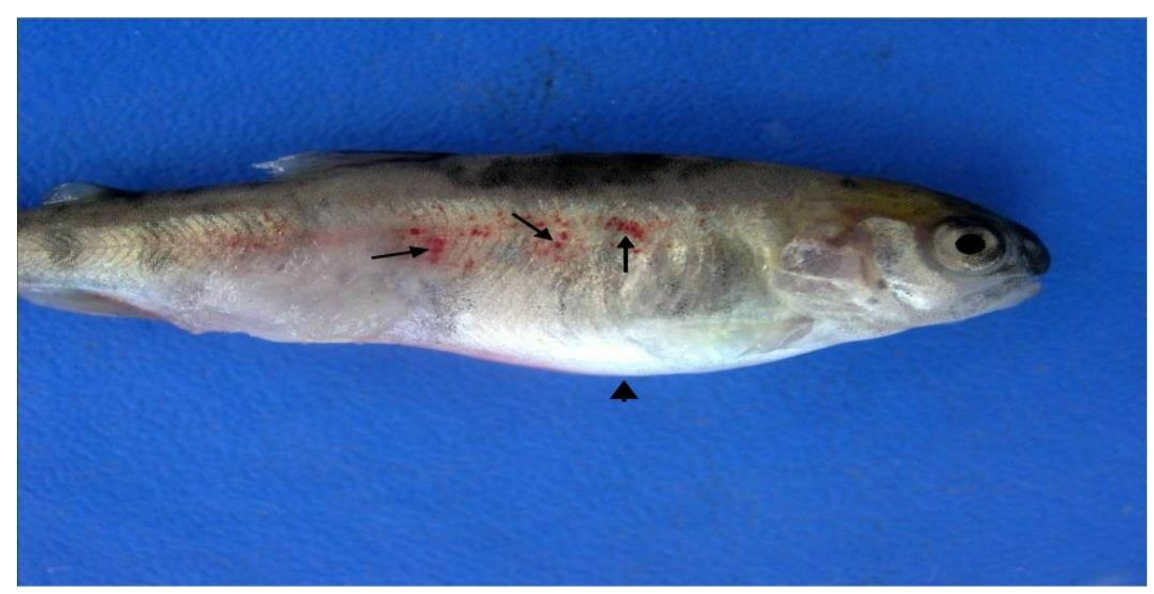

Şekil 1: Flavobacterium psychrophilum enfeksiyonu, deride peteşiyel kanama (oklar) ve karın boşluğunda asites (okbaş1), gökkuşağ1 alabalığ1

Figure 1: Flavobacterium psychrophilum infection, petechial hemorrhage on the skin (arrows) and ascites in the abdominal cavity (arrowhead), rainbow trout

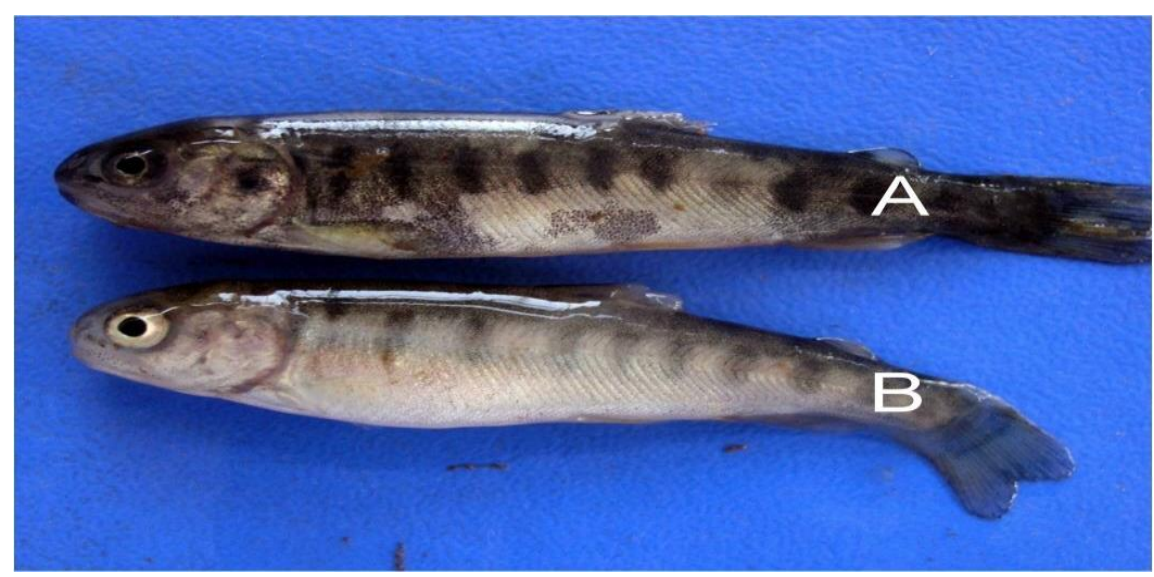

Şekil 2: Flavobacterium psychrophilum enfeksiyonu, deride renkte koyulaşma (A), kontrol (B), gökkuşağ1 alabalığ1

Figure 2: Flavobacterium psychrophilum infection, darkening in skin (A), control (B), rainbow trout

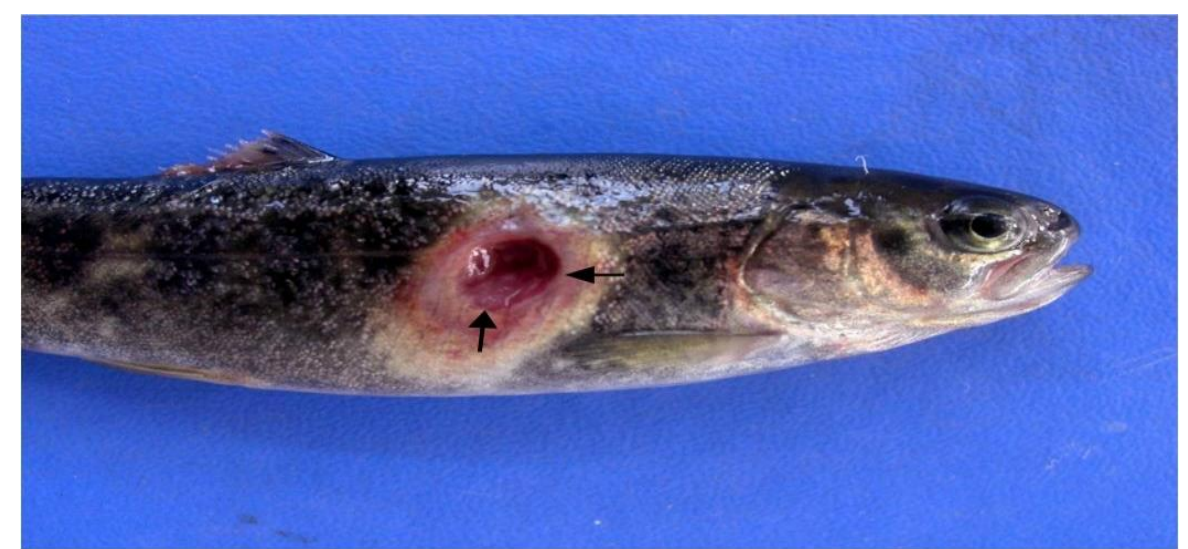

Şekil 3: Flavobacterium psychrophilum enfeksiyonu, deride derin ülser (oklar), gökkuşağı alabalığ1

Figure 3: Flavobacterium psychrophilum infection, deep ulcer on the skin (arrows), rainbow trout 

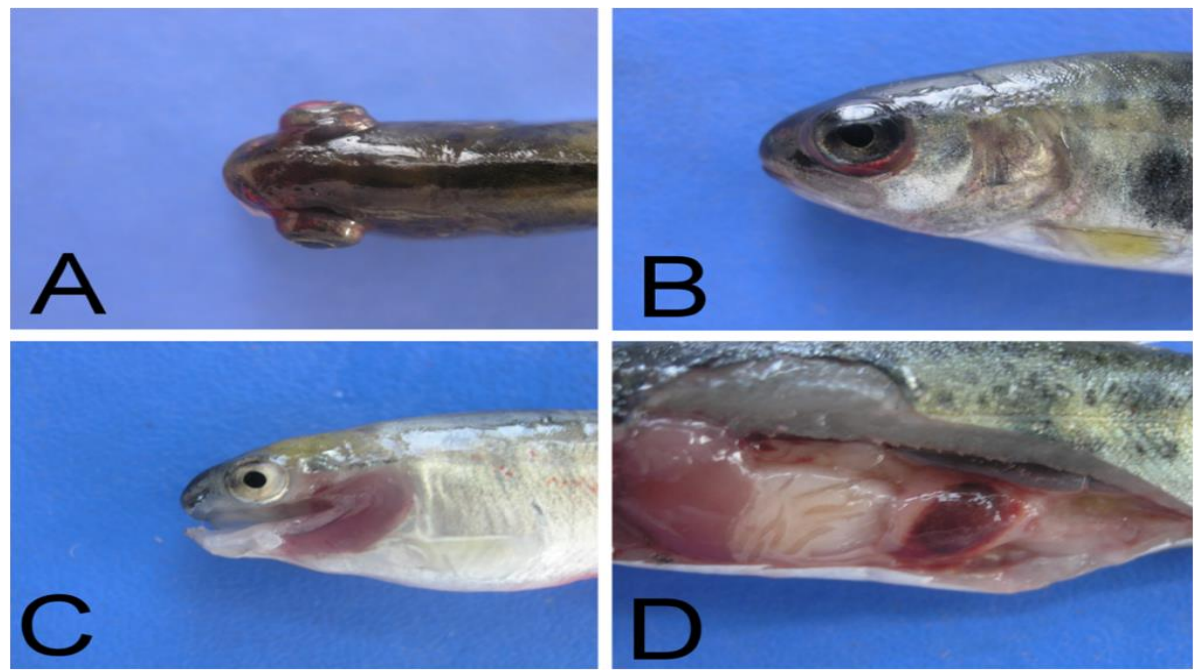

Şekil 4: Flavobacterium psychrophilum enfeksiyonu, gözde bilateral ekzoftalmus (A), perioküler kanama (B), solungaçlarda anemi (C), dalakta şişkinlik, konjesyon ve çevresinde kanama (D)

Figure 4: Flavobacterium psychrophilum infection, bilateral exophthalmus in the eye (A), periocular hemorrhage (B), anemia in the gills (C), swelling of the spleen, congestion and hemorrhage around it (D)

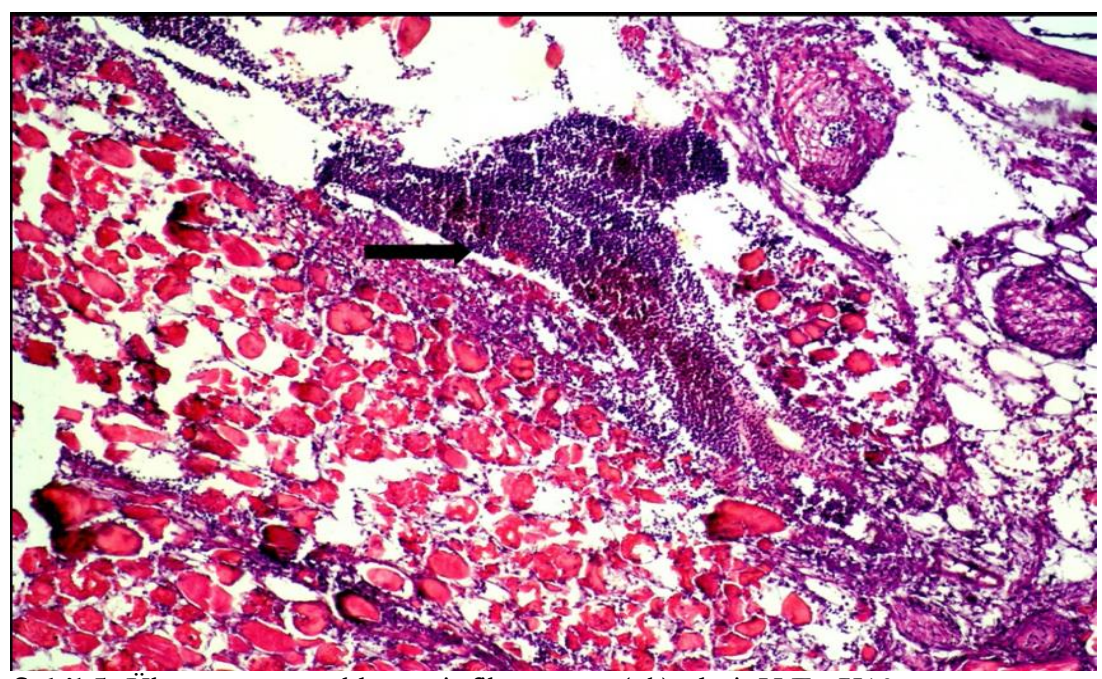

Şekil 5. Ülser ve yang1sal hücre infiltrasyonu (ok), deri, H.E., X10

Figure 5. Ulcer and inflammatory cell infiltration (arrow), skin, H.E., X10

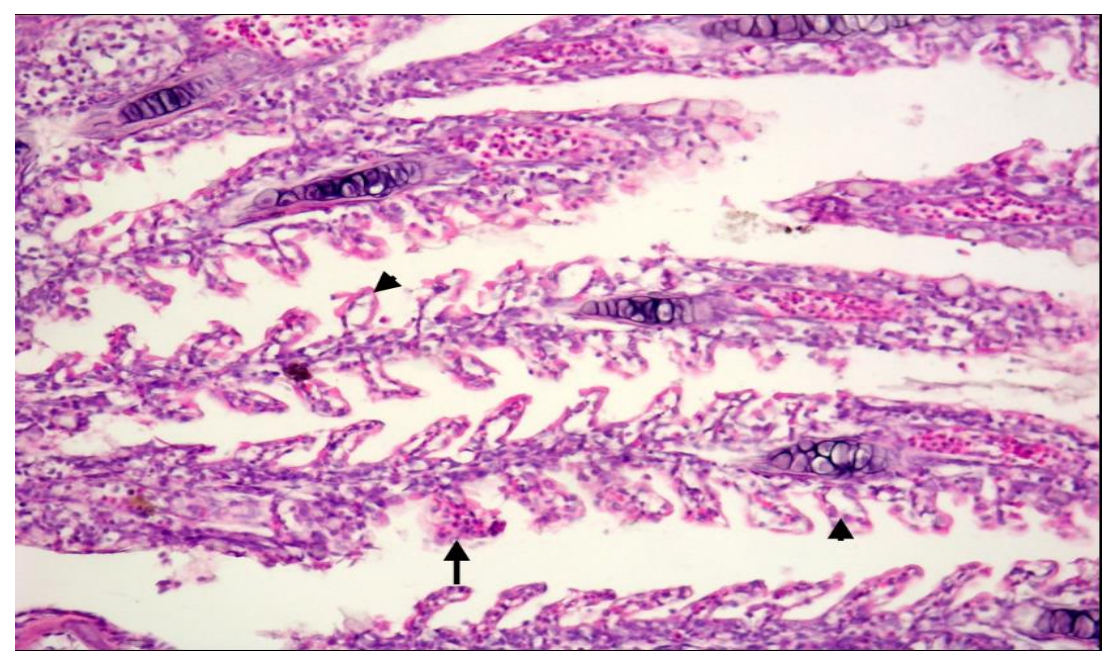

Şekil 6: Sekonder lamellerde ödem (ok başı) ve telangiektazi (ok), solungaç, H.E., X20

Figure 6. Edema (arrowhead) and telangiectasia (arrow) in secondary lamellae, gill, H.E., X20 


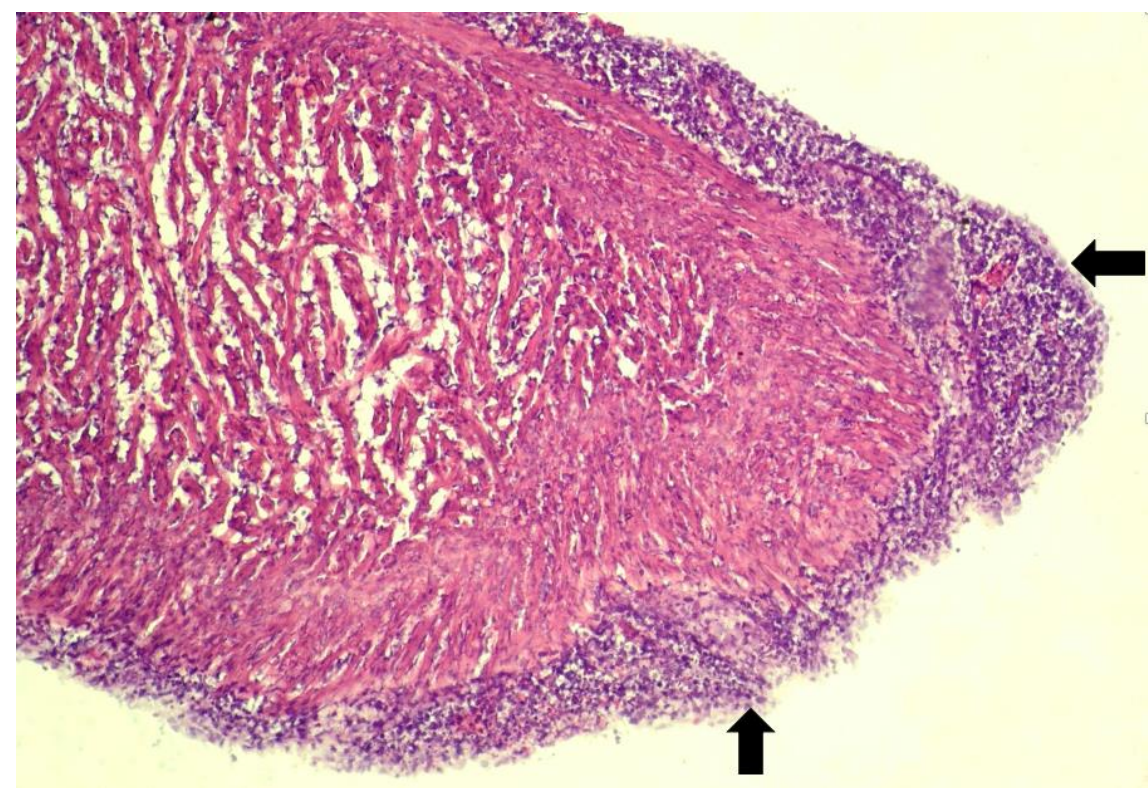

Şekil 7: Epikartta yang1sal hücre infiltrasyonu (oklar), kalp, H.E., X10

Figure 7. Inflammatory cell infiltration (arrows) in the epicardium, heart, H.E., X10

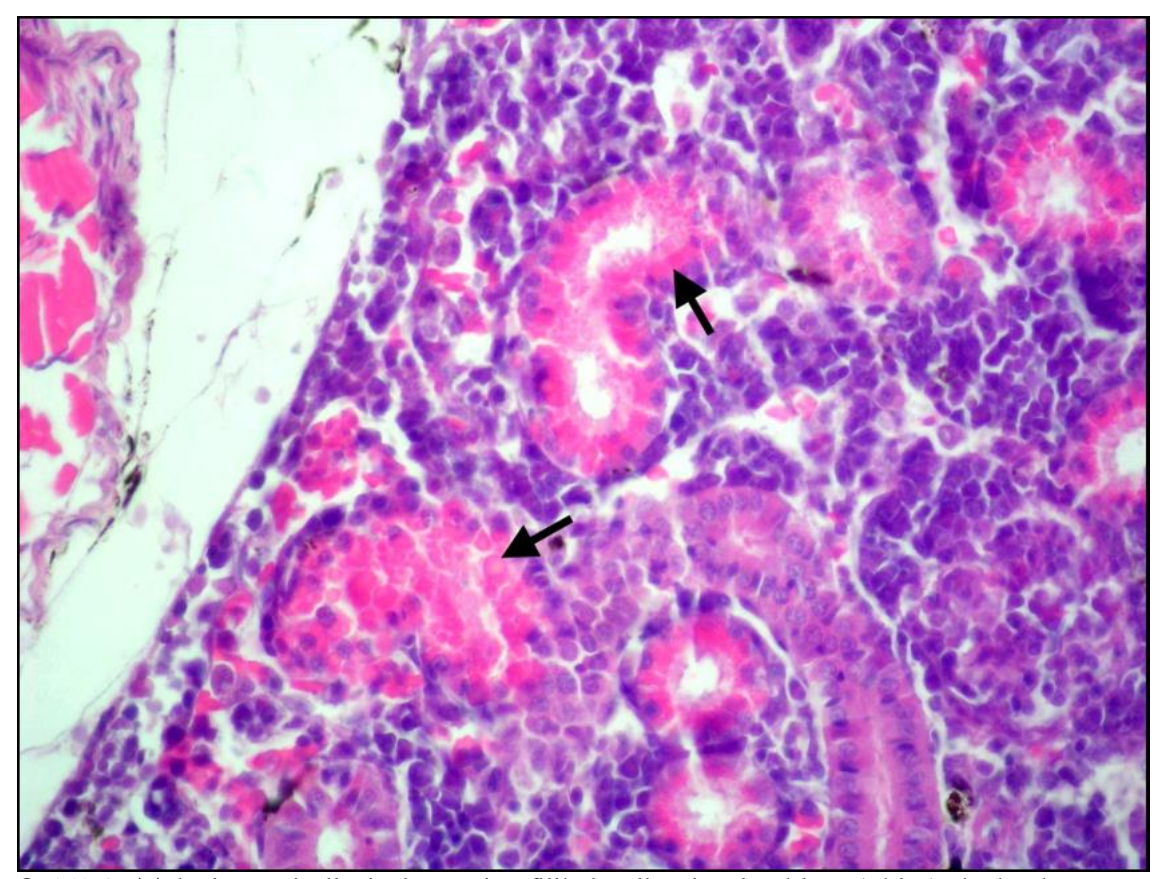

Şekil 8. Tubulus epitellerinde eozinofilik hyalin damlacıkları (oklar), böbrek, H.E., X40

Figure 8. Eosinophilic hyaline droplets (arrows) in tubulus epithelium, kidney, H.E., X40 
Tablo 1. Alabalıklardan izole edilen Flavobacterium psycrophilum'un morfolojik ve biyokimyasal özellikleri

Table 1. Morphological and biochemical properties of Flavobacterium psycropbilum isolated from rainbow trouts

\begin{tabular}{lclccc}
\hline & Sonuç & Hidrolizasyon & Sonuç & Üreme & Sonuç \\
\hline Sarı Pigmentli Koloni & + & Eskulin & - & $4{ }^{\circ} \mathrm{C}$ & + \\
Gliding Hareket & + & Kitin & - & $25{ }^{\circ} \mathrm{C}$ & - \\
Gram Boyama & - & Agar & - & $37^{\circ} \mathrm{C}$ & - \\
O/F Metabolizma & $\mathrm{O}$ & Jelatin & + & $\% 0,5 \mathrm{NaCl}$ & + \\
Katalaz & + & Nişasta & - & $\% 1 \mathrm{NaCl}$ & - \\
Oksidaz & - & Kazein & + & $\% 2 \mathrm{NaCl}$ & - \\
İndol & - & Tributirin & + & $\% 3 \mathrm{NaCl}$ & - \\
Nitrat & - & Tween 20 & + & $\% 1$ Tripton & + \\
$\mathrm{H}_{2} \mathrm{~S}$ & - & Tween 80 & + & & \\
\hline
\end{tabular}

Tablo 2. Alabalıklardan izole edilen Flavobacterium psycrophilum'un API 20E identifikasyon sistemi ile belirlenen biyokimyasal özellikleri

Table 2. Biochemical properties of Flavobacterium psycrophilum isolated from rainbow trouts determined by API 20E identification system

\begin{tabular}{lclc} 
& Sonuç & Şekerden asit üretimi & Sonuç \\
\hline ONPG & - & Glukoz & - \\
ADH & - & Mannitol & - \\
LDH & - & İnositol & - \\
ODC & - & Sorbitol & - \\
Sitrat & - & Ramnoz & - \\
$\mathrm{H}_{2} \mathrm{~S}$ & - & Sukroz & - \\
Üre & - & Melibioz & - \\
TDA & - & Amigdalin & - \\
İndol & - & Arabinoz & - \\
VP & - & Oksidaz & - \\
Jelatin & + & & \\
\hline
\end{tabular}

\section{TARTIŞMA}

F. psychrophilum'un neden olduğu bakteriyel soğuk su hastalığı, dünyanın birçok yerinde bulunan alabalık çiftliklerinde hastalık salgınlarına ve önemli ekonomik sorunlara yol açmaktadır (Roberts 2001, Nematollahi ve ark. 2003). Gökkuşağ1 alabalıklarında, F. psychrophilum enfeksiyonunda klinik olarak anoreksi, letarji, deri renginde koyulaşma, asites, bilateral ekzoftalmus ve perioküler kanama gibi bulguların görüldüğü bildirilmiştir (Roberts 2001, Nematollahi ve ark. 2003, Yıldırım ve Özer 2010). Çalışmada durgunluk, yem tüketiminde azalma ve su yüzeyine yakın yüzmeler ile düzensiz yüzme hareketleri şeklinde saptanan klinik bulgular önceki bildirimlerle uyum sağlamış, sıklıkla bildirilen iskelet lezyonlarına bu araştırmada rastlanmamıştır (Madsen ve ark. 2005, Kubilay ve ark. 2009). Pek çok literatürde belirtildiğinin aksine ise karaciğerde solgunluk yerine konjesyon ve şişkinlik belirlenmiştir (Roberts 2001, Ekman ve Norrgren 2003, Yıldirım ve Özer 2010). Sunulan çalışmada dikkati çeken hava keselerinde ödem ve kalınlaşmalara ise önceki çalışma ve raporlarda rastlanmamıştır.

Değişik çalışmalarda deride şekillendiği bildirilen tek taraflı ve derin ülser odakları sunulan çalışmada da yaygın olarak saptanmıştır (Madetoja ve Wiklund 2002, Nematollahi ve ark. 2003). Bu ülserlerdeki yoğun bakteri kümelerinin varlığı, derinin portantre olarak rol oynadı̆̆1 ve bakterilerin suya katılımına kaynak oluşturduğu şeklinde yorumlanmıştır.

Bazı çalışmalarda böbrekte tubulus epitellerinde tanımlanan intrasitoplazmik eozinofilik hyalin damlacıkları sunulan çalışmada da yaygın olarak 
görülmüş, bu bulgular böbreklerdeki proksimal tubulus epitellerinin dejenerasyonlarının bir sonucu olarak değerlendirilmiştir (Ostland ve ark. 2000, Madetoja ve Wiklund 2002, Nematollahi ve ark. 2003).

Dalakta konjesyon, kırmız1 ve beyaz pulpada ödematöz değişiklikler, yaygın hemoraji, splenomegali ve nekroz gibi patolojik bulguların en belirgin olarak gökkuşağ1 alabalıklarında görüldüğü bildirilmiş (Roberts 2001, Ekman ve Norrgren 2003), bu çalışmada ise dalakta makroskobik olarak şişkinlik ve yumuşama; mikroskobik olarak ise sinüzoidlerin eritrositler ile dolu olduğu görülmüştür.

Bazı kronik enfeksiyon vakalarında kalpte perikarditis görüldüğü belirtilmiş (Roberts 2001) ve sunulan çalışmada epikarditis en önemli histopatolojik bulgulardan biri olarak kaydedilmiştir. Balıklarda yaygin olarak görülen hiperemi ve kanamalar da kalp yetmezliği ile ilişkilendirilmiş ve epikarditis görülen balıklarda bunun birincil ölüm nedeni olduğu sonucuna varılmıştır.

F. psychrophilum enfeksiyonunda alabalıklarda solungaçlarda anemiye bağlı solgunluk, hiperemi ve peteşiyel kanama gibi bulguların görüldüğü bildirilmiş (Roberts 2001, Nematollahi ve ark. 2003), sunulan çalışmada da solungaçlarda yaygın olarak primer lamellerde hiperemi ile sekonder lamellerde ödem, epitellerde dejenerasyon ve dökülmeler belirlenmiştir. Bilinen solungaç lezyonlarının yanı sıra solungaçlarda bol miktarda yabanc1 partikülün bulunması, su kirliliği ile hastalığın şiddetini ve mortalite oranını artıran bir faktör olarak yorumlanmıştır. $\mathrm{Bu}$ durum, su kirliliğinin, enfeksiyonun yayılması ile patogenezinde oynadığ1 rol (Roberts 2001) ve işletmeye verdiği zararın oldukça önemli olduğunu ortaya koymuştur. Hastalığın teşhisinde patolojik incelemelerin yanında mikrobiyolojik izolasyon ve identifikasyon da önemli yer tutmaktadır. Özellikle etkenin izolasyonunda klasik agarlara göre Cytophaga Agar daha s1k kullanılmakta, bu agarda kenarları ince ve parlak sar1 kolonilerin ürediği dikkati çekmektedir (Nematollahi ve ark. 2003). Bu çalışmada da Cytophaga Agar üzerinde 10 günde saf olarak sarı renkli koloniler üremiş ve etkenin morfolojik ve biyokimyasal karakterleri incelendiğinde, etken F. psychrophilum olarak identifiye edilmiştir.

\section{SONUÇ}

Sonuç olarak, bu çalışmada, iki ayrı alabalık işletmesinde ortaya çıkan F. psychrophilum enfeksiyonu patolojik bulguları ve bakteriyolojik analizleri ile tanımlanmıştır. Yavru alabalıklarda doğal olarak şekillenen ve bu enfeksiyonun ortalama $1 \pm 02 \mathrm{~g}$ ağırlı̆̆ındaki yavru balıklarda klinik olarak ekzoftalmus, makroskobik ve mikroskobik olarak erozyon, ülser ve yine mikroskobik olarak epikarditis ile seyrettiği düşünüldüğünde; benzer bulguların işletmelerde fark edilmesi durumunda, mortalite oran1 oldukça yüksek olabilen bu hastalığın göz önüne alınarak buna ilişkin koruma ve kontrol önlemlerinin alınması gerektiği kanısına varılmıştır.

Çıkar Çatışması: Yazarlar, çıkar çatışması olmadığını beyan eder.

\section{KAYNAKLAR}

Austin D, Austin DA. Bacterial fish pathogens: Disease of farmed and wild fish, Ellis Horwood Ltd. 1987.

Austin D, Austin DA. Bacterial fish pathogens: Diseases of farmed and wild fish, 4th Ed., Springer and Praxis Publishing, Chichester, UK. 2007.

Boyacioğlu M, Akar F. Isolation of Flavobacterium psychrophilum causing rainbow trout fry syndrome and determination of an effective antibacterial treatment in rainbow trout (Oncorbynchus mykiss) fry. Kafkas Univ Vet Fak Derg. 2012; 18 (2): 197-203.

Ekman E, Norrgren L. Pathology and immunohistochemistry in three species of salmonids after experimental infection with Flavobacterium psychrophilum. J Fish Dis. 2003; 26: 529538.

Kubilay A, Altun S, Didinen BI, Ekici S, Diler Ö. Gökkuşağı alabalı̆̆1 (Oncorbynchus mykiss) işletmelerinde Flavobacterium psychrophilum izolasyonu. Kafkas Univ Vet Fak Derg. 2009, 15: 709-715.

Madetoja J, Wiklund T. Detection of the fish pathogen Flavobacterium psychrophilum in water from fish farms. Syst Appl Microbiol. 2002; 25: 259-266.

Madsen L, Moller JD, Dalsgaard I. Flavobacterium psychrophilum in rainbow trout (Oncorbynchus mykiss Walbaum) hatcheries: Studies on broodstock, eggs, fry and environment. J Fish Dis. 2005; 28: 39-47.

Nematollahi A, Decostere A, Pasmans F, Haesebrouck F. Flavobacterium psychrophilum infections in salmonid fish. J Fish Dis. 2003; 26: 563-574.

Ostland VE, Byrne PJ, Hoover G, Ferguson HW. Necrotic myositis of rainbow trout Oncorbynchus mykiss (Walbaum): Proteolitic characteristics of a crude extracellular prepation from Flavobacterium psychrophilum. J Fish Dis. 2000; 23: 329-336.

Pacha RE, Porter S. Characteristics of Myxobacteria Isolated from the Surface of Freshwater Fish. Appl Microbiol. 1968; 16: 19011906.

Reichenbach H, Dworkin M. The order myxobacterales, In: The Prokaryotes, Ed; Starr MP, Stolp H, Trüper HG, Balows A, Schlegel HG, Springer-Verlag, Berlin, Germany. 1981; pp. 356-379.

Roberts RJ. Fish Pathology, W.B. Saunders. 2001; pp. 299-304.

Yıldırım S, Özer S. Mersin ili çağlarca köyündeki gökkuşağı alabalığ1 (Oncorbynchus mykiss, walbaum, 1792) kuluçkahanelerinde Flavobacterium spp. varllğı. J Fish Sci. 2010; 4 (1): 112-122. 